\title{
5 Archivists for human rights
}

In catering to the massive and unprecedented influx of police and intelligence service records from former dictatorships, National Archives in countries newly on the road to democracy were often handicapped in their efforts to preserve this vulnerable documentary heritage by the unfamiliar problems they faced with regard to its processing and access. In 1993, at the International Conference of the Round Table on Archives ${ }^{37}$ (CITRA) in Mexico, a group of experts was tasked by UNESCO and the International Council on Archives with drafting a report on the management of the archives of the security services of former repressive regimes. The group, headed by Antonio González Quintana, delivered its report in 1995. This underlined the fundamental role of these archives in guaranteeing citizens their collective and individual rights, because police files used to keep people under duress were, ironically, the best weapons for ensuring individual rehabilitation and collective reconciliation.

The report's final recommendations included the collective rights of people to all aspects of their memory, to truth, to know those responsible for crimes against human rights and the individual rights of victims and their families to know the whereabouts of vanished family members, to rehabilitation, to know what information is held on them, to amnesty in the case of political prisoners and to reparation and return of confiscated goods.

The Joinet and González Quintana reports were authored by experts with two completely different profiles: one coming from a legal, the other from an archival perspective. These reports were drawn up completely independently of each other, yet they came to exactly the same conclusions, albeit worded slightly differently. The extraordinary convergence between the magistrate's findings and those of the archivist went more or less undetected, the two professions tending to work in silos. Most archivists ignored the existence of Louis Joinet's report, even those in France who had heard of Joinet but only in a strictly national context. ${ }^{38}$ The González Quintana report, for its part, was published as an official document in English in hard and soft copy versions by UNESCO. ${ }^{39}$ It was also published in French in Janus, a professional journal with limited circulation. Outside a small group of archivists with an interest in international issues, very few people knew 
of its existence, even though it addressed a highly topical subject relevant to the public as a whole in many countries.

It was only in 2003, in Cape Town, South Africa that, for the first time, the notions of archives and human rights were addressed together at an international conference. This Conference was organised exclusively for the Directors of National Archives and the Presidents of National Associations and Sections of the International Council on Archives (ICA) and was the occasion for leaders of the profession to discuss strategic issues. Within the ICA, which is an international organization funded by countries, not all with democratic regimes, the question of human rights has always been a particularly sensitive issue, the expression "human rights" in itself carrying activist connotations upsetting to certain members of the profession.

Earlier meetings had been held in Latin America and in Central and Eastern Europe in response to demands from historians for access to these new sources of information. They also reflected the determination of human rights campaigners to contest the amnesty laws introduced by certain governments and insist on accountability so that reparations could be obtained (González Quintana, 2009, pp. 31-32). These events were local or regional in nature and the ICA was not involved.

The invitation from South Africa to host the 2003 Conference was an ideal opportunity to address the issue of archives and human rights, not least following the outstanding efforts of the country's Truth and Reconciliation Commission and the recent transfer of its records to the South African National Archives. For the archival community, the conference was a flagship event and the words of Desmond Tutu, Chairman of the Truth and Reconciliation Commission and winner of the Nobel Peace Prize, in his inaugural speech remain engraved in our collective memory:

We are ashamed of that part of our history, but it is our history nonetheless. And it stands there recorded in our National Archives.... The records are crucial to hold us accountable. . . They are a potent bulwark against human rights violations. We must remember our past so that we do not repeat it.

(ICA, 2004)

The Cape Town Conference played a decisive part in driving home the links between archives and human rights and the vital role of archives in transitional societies as instruments for the defence of individual and collective rights in countries formerly the scene of gross human rights violations. It also clearly revealed the need to recognise the vulnerability of such records and to adopt a professional approach to their curation. The conference concluded with a series of resolutions intended for the public authorities and international organizations, urging them to ensure that archival fonds providing documentary evidence of crimes committed were preserved and held in safekeeping, in particular records of State security services, police, truth 
and reconciliation commissions, international criminal courts and tribunals, international human rights defence organizations and non-governmental organizations. These national and international bodies were also urged to publicise the existence of and facilitate access to this material.

Another decision concerned the creation of a small working group on archives and human rights within the ICA to follow up on the Conference resolutions and maintain the momentum thus created. During the Conference, one of the things to have been brought into focus was the extent to which different professions tended to work in splendid isolation, in ignorance of what was happening in other sectors: society knew little of the world of archives and, at best, thought of them in purely cultural and heritage-related terms, while archiving was traditionally a low-key profession. The working group decided, therefore, to embark on a number of initiatives geared towards alerting public opinion, human rights defence protagonists and archivists.

The 1995 report on the archives of security services required updating and needed to be extended to take account of the latest considerations. A new document was, therefore, published by Antonio González Quintana in 2009 under the title Archival policies in the protection of human rights. This no longer focused exclusively on police and intelligence service archives but also included the archives of transitional justice institutions (extra-judicial commissions of inquiry and international criminal tribunals) and those of human rights organizations.

The report makes the case for comprehensive archiving policies treating all official documents in a professional manner and also supporting private archives. It urges the public authorities to take action to ensure that archives relating to periods of oppression are preserved and used under conditions guaranteeing their physical safety and to introduce legislation and regulations to protect the interests of the State and the individual. It also insists on the need for National Archives to be provided with the necessary human and material resources.

Communication activities were also stepped up and, since 2008, the group has been publishing a monthly newsletter ${ }^{40}$ giving national and international information and announcing recent or upcoming publications in the field. The newsletter is widely circulated and readers are encouraged to share its content. There are three language versions (English, French and Spanish) that can be downloaded from the ICA website. ${ }^{41}$

Efforts have also been made to make the preservation and processing of these archives more professional from the outset in low-resource organizations through the publication of a guide entitled "The records of NGOs: memory to be shared", which exists in several languages, including English and French, ${ }^{42}$ and the development of an open-source application for standardsbased archival description and access in a multilingual environment that rejoices in the name of AtoM (Access to Memory) and is designed to explain and simplify the process of uploading archival holdings. ${ }^{43}$ A number of 
studies have been published by Trudy Huskamp Peterson: a guide to preserving records of truth commissions (2005), a report on the records of the international criminal tribunals (2006) and a guide to securing police archives (2013).

Various events have been organised to inform governments, civil society and the international community of the political, legal, historical and memorial challenges these archives represent and the risks to which they are exposed. Encounters between archivists, human rights advocates and the legal profession have proved highly fruitful and have rapidly been translated into action. Through the intermediary of Louis Joinet, contacts established with the Office of the High Commissioner for Human Rights and the Human Rights Commission have enabled the wheels to be set in motion in the United Nations to obtain due recognition for the importance of archives in relation to the right to truth and have made it possible for the recommendations and guidelines mentioned earlier to be adopted.

On a parallel to these developments, the closing years of the 20th century and the early years of the 21st century were marked by the number of major contributions to critical thinking on this subject produced in academic circles. Many of them were the work of professors and archivists in different parts of the world, all proponents of the latest schools of archival thought, such as postmodern archival theory, resolutely in favour of changes in the role of the profession.

John Ridener (2009) provides a comprehensive overview of the changes in archival theory from the publication of Muller, Feith and Fruin's "Dutch Manual" in 1898 up to the period he calls "Questioning", which he addresses in his final chapter. For Ridener, this period may be situated between 1991 and 2004 and revolves around five archivists: Brien Brothman (1993), Terry Cook (1997), Carolyn Heald (1996), Eric Ketelaar (2003) and Laurie McNeil (2003). Other names should perhaps be added to this list, for example Tom Nesmith (2002) and Verne Harris (1997). The fathers of postmodern archival theory and, to an even greater extent, their successors argue in favour of the absolute need for activism in Archives as institutions but also, more importantly, for activism among archival practitioners. They argue that these institutions and those that work in them should transform archives into instruments of social justice, irrespective of traditional guidelines centred on the best preservation of official records. Consequently, they consider that it should be up to the rest of society to decide which records should be selected for permanent preservation. SouthAfrican archivist Verne Harris (2007) is probably the most outspoken advocate of this approach.

But postmodern archival theorists were not the only professionals involved in this major rethink of the purpose of archives and records. Archival organizations and many archival institutions have therefore cast themselves in a new social role, first and foremost in highlighting the importance of records and archives for guaranteeing individual rights and the 
administrative transparency of public organizations. In 1998, the nongovernmental organization Archivists without Borders (AwB) was founded in Barcelona. This soon spread with the creation of chapters in some dozen countries in Europe and the Americas. One of its primary objectives is that of preserving archives and documentary heritage relating to the gross human rights violations perpetrated in totalitarian countries and facilitating access to these records for victims and in the interests of justice. ${ }^{44}$ Its president and co-founder, Ramón Alberch i Fugueras, has highlighted the close links between preserving archives and the struggle for human rights (Alberch $\mathrm{i}$ Fugueras, 2008).

Other protagonists have taken up the cause and have been particularly involved in ensuring application of the Joinet/Orentlicher Principles and providing protection for these archives, a case in point being Switzerland. In 2011, the SwissPeace foundation joined forces with the Swiss Federal Archives and the Federal Department of Foreign Affairs to embark on a project called Archives and Dealing with the Past.$^{45}$ Swisspeace prefers the expression "dealing with the past" to that of transitional justice to underline the long-term nature of a process that is non-linear and requires complicated negotiations with a variety of other protagonists. A conceptual framework was established for this project and is based on the four pillars of the right to know, the right to justice, the right to reparation and the guarantee of nonrecurrence. ${ }^{46}$ The aim is to contribute towards ensuring that archives documenting human rights violations in transitional or post-conflict countries are suitably preserved and made accessible by establishing links between human right advocates involved in transitional justice processes and archival experts.

The foundation also provides a platform for exchanges of good practices for archival and transitional justice practitioners. Its website offers a very comprehensive list of international reference documents and a bibliography of works and articles published in this field. In 2017, it published a manual with the title Mapping Archives for Dealing with the Past Processes (Baumgartner and Peterson, 2017) which describes the stages involved in professionally mapping the archives needed for dealing with the past: where they are located, the information they contain, to whom they are accessible, identify the records at risk and the measures to be taken to secure them. This was based on the experiences of Tunisia's Truth and Dignity Commission Part 2, Chapter 3 by Adel Maïzi.

The Basic Principles on the role of Archivists and Records Managers in Support of Human Rights ${ }^{47}$ were produced by applying the approach adopted for the Basic Principles on the Role of Lawyers. For their part, the ICA Code of Ethics and the Universal Declaration on Archives, endorsed by UNESCO in 2011, establish a framework for the responsibilities incumbent on the profession but are couched in very general terms. The main purpose of these Principles is to support archivists faced with the complex ethical, legal and practical problems they are bound to encounter when dealing with 
records with human rights implications by providing them with helpful guidelines. Archivists often work in isolation and may be pressurised into destroying comprising documents or into omitting them from their finding aids.

Their second purpose is to help international officials dealing with human rights issues to understand the contribution that professional archivists and records managers can make to the protection of human rights. Some UN reports on human rights fail to mention the need to preserve archives and records. One classic example is the UN Guiding Principles on Business and Human Rights, otherwise known as the Ruggie principles (2011), named after John Ruggie, their rapporteur. Yet businesses need records managers to guarantee traceability, combat impunity and prevent abuse.

The Basic Principles encourage archivists to preserve the integrity of archives and their value as evidence of human rights violations and prevent their destruction, to consider the utility of a given body of archives to support human rights claims when selecting documents (identification of perpetrators of human rights violations, resolving the fate of missing persons or obtaining reparation), to waste no time and give priority to producing descriptions of such archival fonds, to afford access to these records for victims, even if they are not available to the general public (while being careful not to divulge confidential personal data) and not to make distinctions between prosecutors and defendants. ${ }^{48}$

They confirm that archivists who discover archives that contain evidence of gross human rights violations should inform the relevant authorities about the existence of such archives and Governments should provide them with channels to report such violations; and that they have the right to report to an appropriate authority any retaliatory measures or threats of retaliation in relation to the disclosure, provided that they have previously tried to use the existing internal reporting mechanisms. They should urge institutions to respect the cultural heritage of countries and communities and not acquire archives which do not fall within their jurisdiction. They should cooperate with institutions in other countries to settle claims about disputed displaced archives in a spirit of fairness and mutual respect.

In 2019, the working group was promoted to the status of ICA Professional Section, the Section on Archives and Human Rights (SAHR). This has the advantage of giving the group greater legitimacy and securing its financial resources as well as raising its profile inside and outside ICA. 